\title{
BIOMECHANICS AT MICRO- AND NANOSCALE LEVELS
}

VOLUME I 
This page is intentionally left blank 


\title{
BIOMECHANICS AT MICRO- AND NANOSCALE LEVELS \\ VOLUME I
}

\author{
editor \\ Hiroshi Wada \\ Tohoku University, Sendai, Japan
}


Published by

World Scientific Publishing Co. Pte. Ltd.

5 Toh Tuck Link, Singapore 596224

USA office: 27 Warren Street, Suite 401-402, Hackensack, NJ 07601

UK office: 57 Shelton Street, Covent Garden, London WC2H 9HE

\section{British Library Cataloguing-in-Publication Data}

A catalogue record for this book is available from the British Library.

\section{BIOMECHANICS - AT MICRO- AND NANOSCALE LEVELS Volume I}

Copyright ( 2005 by World Scientific Publishing Co. Pte. Ltd.

All rights reserved. This book, or parts thereof, may not be reproduced in any form or by any means, electronic or mechanical, including photocopying, recording or any information storage and retrieval system now known or to be invented, without written permission from the Publisher.

For photocopying of material in this volume, please pay a copying fee through the Copyright Clearance Center, Inc., 222 Rosewood Drive, Danvers, MA 01923, USA. In this case permission to photocopy is not required from the publisher.

ISBN 981-256-098-X 


\section{PREFACE}

A project on "Biomechanics at Micro- and Nanoscale Levels," the title of this book, was approved by the Ministry of Education, Culture, Sports, Science and Technology of Japan in 2003, and this four-year-project is now being carried out by fourteen prominent Japanese researchers. The project consists of four fields of research, which are equivalent to four chapters of this book, namely, Cell Mechanics, Cell Response to Mechanical Stimulation, Tissue Engineering, and Computational Biomechanics.

Our project can be summarized as follows. The essential diversity of phenomena in living organisms is controlled not by genes but rather by the interaction between the micro- or nanoscale structures in cells and the genetic code, the dynamic interaction between them being especially important. Therefore, if the relationship between the dynamic environment of cells and tissues and their function can be elucidated, it is highly possible to find a method by which the structure and function of such cells and tissues can be regulated. The first goal of this research is to understand dynamic phenomena at cellular and biopolymer-organelle levels on the basis of mechanics. An attempt will then be made to apply this understanding to the development of procedures for designing and producing artificial materials and technology for producing or regenerating the structure and function of living organisms.

We are planning to publish a series of books related to this project, this book being the first in the series. The trend and level of research in this area in Japan can be understood by reading this book.

Hiroshi Wada, $\mathrm{PhD}$,

Project Leader,

Tohoku University,

Sendai,

March, 2004. 
This page is intentionally left blank 


\section{CONTENTS}

\section{PREFACE}

I. CELL MECHANICS 1

Imaging and mechanical properties of guinea pig outer hair cells

studied by atomic force microscopy

H. Wada, M. Sugawara, K. Kimura, Y. Ishida, T. Gomi,

M. Murakoshi, Y. Katori, S. Kakehata, K. Ikeda and

T. Kobayashi

Development of a novel micro tensile tester for single isolated

cells and its application to viscoelastic analysis of aortic smooth muscle cells

T. Matsumoto, J. Sato, M. Yamamoto and M. Sato

Shear dependent albumin uptake in cultured endothelial cells

K. Tanishita, M. Shimomura, A. Ueda, M. Ikeda and S. Kudo

Biomechanical and biotribological importance of surface and

surface zone in articular cartilage

T. Murakami, Y. Sawae, N. Sakai and I. Ishikawa

\section{CELL RESPONSE TO MECHANICAL STIMULATION}

Osteoblastic mechanosensitivity to localized mechanical stimulus depends on orientation of cytoskeletal actin fibers

T. Adachi and K. Sato

Microbiomechanical properties of cultured endothelial cells

estimated by atomic force microscopy

M. Sato

Effects of mechanical stresses on the migrating behavior of endothelial cells

T. Tanaka, K. Naruse and M. Sokabe 
Engineering approaches to regulate cell differentiation and tissue regeneration

T. Ushida, K. S. Furukawa, G. Chen and T. Tateishi

A new theory on the localization of vascular diseases

T. Karino, S. Wada and T. Naiki

Automorphogenesis of load bearing fibrous tissues: Generation of tensile stress, cell alignment, and matrix deformation by fibroblasts

K. Takakuda

IV. COMPUTATIONAL BIOMECHANICS

Note on anisotropic properties of cancellous bone and trabeculae:

Elasticity and hardness

M. Tanaka, T. Matsumoto, M. Ihara and M. Todoh

Application of computational biomechanics to clinical cardiovascular 134 medicine

T. Yamaguchi

Biomechanical study for skeletal muscle injury and a view of micro-biomechanics for microstructure of muscle

S. Yamamoto and E. Tanaka

Mechanical behavior and structural changes of cells subjected to mechanical stimuli: Deformation, freezing, and shock waves

H. Yamada, H. Ishiguro and M. Tamagawa 